optimise the chemical composition of an artificial saliva. Four factors were combined in a Franquart experimental design : the amount of $\mathrm{HPO}_{4}{ }^{2-}$ (coded variable $\mathrm{HP}$; $\left.-1=0.1 \mathrm{~g} \mathrm{l}^{-1},+1=4 \mathrm{~g} \mathrm{l}^{-1}\right)$, the amount of $\mathrm{HCO}_{3}^{-}$(coded variable $\mathrm{HC} ;-1=0.5 \mathrm{~g} \mathrm{l}^{-1}$, $+1=7 \mathrm{~g} \mathrm{l}^{-1}$ ), the amount of $\mathrm{Cl}^{-}$(coded variable $\left.\mathrm{C} ;-1=0.1 \mathrm{~g} \mathrm{l}^{-1},+1=0.5 \mathrm{~g} \mathrm{l}^{-1}\right)$, and the ratio $\mathrm{Na}^{+} / \mathrm{K}^{+}$(coded variable $\mathrm{R} ;-1=0.5 \mathrm{~g}$ $\left.\mathrm{g}^{-1},+1=15 \mathrm{~g} \mathrm{~g}^{-1}\right)$. The fermentors were supplied with $22.5 \mathrm{~g} \mathrm{~d}^{-1}$ orchard-grass hay and $7.5 \mathrm{~g} \mathrm{~d}^{-1}$ ground barley during 3 sevenday periods. Using the coded factors, second order polynomial models were fitted to the data by multiple linear regression.

The action of minerals on methane production and protozoa involved to an equal degree several experimental factors with a nonlinear behavior. The amount of methane produced ranged from 0.85 to $1.58 \mathrm{mmol} \mathrm{h}^{-1}$. When selecting the coefficient estimates different from null at the $\mathrm{p}$ value of 0.15 , the polynomial for methane production rate was $Y_{M}=1.54+0.15 \mathrm{HC}$ $+0.08 \mathrm{C}-0.14 \mathrm{R}-0.49 \mathrm{HP}^{2}-0.38 \mathrm{HC}^{2}$ $0.28 \mathrm{R}^{2}-0.31 \mathrm{HP}^{*} \mathrm{HC}+0.41 \mathrm{HP}^{*} \mathrm{C}+0.23$ $\mathrm{HC}^{*} \mathrm{C}$ (Adj R-sq=0.90, root $\mathrm{MSE}=$ $0.063 \mathrm{mmol} \mathrm{h}^{-1}$ ). The protozoa population density, comprised between 14 and $35 \mu^{\circ}$ 1, was favored by high $\mathrm{Na}^{+} / \mathrm{K}^{+}$ratios. The model for protozoa density was $Y_{P}=25.7$ $-3.9 \mathrm{C}+4.0 \mathrm{R}-11.8 \mathrm{HC}^{2}+7.0 \mathrm{R}^{2}-9.8$ $\mathrm{HP} * \mathrm{HC}$ (Adj R-sq=0.76, root $\mathrm{MSE}=$ $2.75 \mu \mathrm{l}^{-1}$ ). The composition of a mineral base was optimized by the technique of desirability function maximization, to simultaneously sustain the in vitro maintenance of protozoa and the activity of methanogens. The resulting artificial saliva contained $4.19 \mathrm{~g} \mathrm{l}^{-1} \mathrm{HCO}_{3}^{-}, 1.65 \mathrm{~g} \mathrm{l}^{-1}$ $\mathrm{HPO}_{4}{ }^{2-}$ and $0.22 \mathrm{~g} \mathrm{l}^{-1} \mathrm{Cl}^{-}$and had a Na$/ \mathrm{K}^{+}$ ratio of $14.2 \mathrm{~g} \mathrm{~g}^{-1}$, and was close to the buffer proposed by Rufener et al. [2].
1. Hoover WH, Crooker BA, Sniffen CJ (1976) J Anim Sci 43, 528-534

2. Rufener WH, Nelson WO, Wolin MJ (1963) Appl Microbiol 11, 196-201

A phylogenetic assessment of bovine rumen methanogens during perturbation by acidosis. $\mathrm{R}$ Sharp ${ }^{1^{*}}$, CJ Ziemer $^{2}$, DA Stahl' ('Civil Engineering, Northwestern University, Evanston, IL 60208, USA; ${ }^{2}$ Animal Science, University of Minnesota, 130 Haecker Hall, 1364 Eckles Avenue, St Paul, MN 55108, USA; 'Current address: Dunn Clinical Nutrition Centre, Cambridge, CB2 2DH, UK)

The rumen microbial community is complex and we have little information on the diversity of contributing populations, their activities or possible interactions. Comparative sequencing and molecular probes have provided an important set of tools for describing and quantifying the diversity of ruminal populations, it is however, only the first step. To move beyond the descriptive, it is essential that ruminal population dynamics be related to ruminal processes. In this study we characterised a well recognised disruption of normal ruminal processes resulting from acidosis using group specific small sub-unit (SSU) ribosomal RNA (rRNA) probes together with chemical measures of population abundance.

Populations of Eucarya, Archaea, Methanobacteriaceae, Methanomicrobiales and Desulfovibrio sp. were quantified with SSU rRNA-targeted probes. Cows were fasted for $12 \mathrm{~h}$ before introducing the acidotic diet. Rumen $\mathrm{pH}$ decreased from 6.53 to 5.44 within $10 \mathrm{~h}$ after first feeding the acidotic diet. Correlation between $\mathrm{pH}$ and the quantity of Eucaryotic SSU rRNA 
was positive $(r=0.65 \mathrm{P}<0.01)$. Values declined from $14.4 \pm 2.79(0 \mathrm{~h})$ to $6.8 \pm$ $1.98 \mu \mathrm{g} \mathrm{g}^{-1}$ rumen fluid (16h). The abundance of Eucarya increased when the cows were returned to the normal diet, reaching $40.3 \pm 5.5 \mu \mathrm{g}$ RNA per g rumen fluid at $72 \mathrm{~h}$. Archaea decreased following the induction of acidosis, from $1.4 \pm 0.4$ to $0.4 \pm 0.07 \mu \mathrm{g} \mathrm{g}^{-1}$ rumen fluid at 0 and $72 \mathrm{~h}$ respectively. The population encompassed by the families Methanoplanaceae, Methanomicrobiaceae and Methanocorpusculaceae declined rapidly during the first $16 \mathrm{~h}$. $(0.54 \pm 0.07$ to $0.04 \pm 0.01 \mu \mathrm{g} \mathrm{g}$ $\left.{ }^{1}\right)$ and did not recover. In contrast the Methanobacteriaceae increased after the perturbation (24.3\% of the total Archaea at $\mathrm{Oh}$ and $79.8 \%$ at $72 \mathrm{~h}$ ). These values were positively correlated with Eucaryal biomass ( $r=0.7 \quad \mathrm{P}<0.01$ ). Desulfovibrio sp. SSU rRNA accounted for an average $1.2 \% \pm 0.59$ of the total SSU rRNA abundance. There was a strong positive correlation between the total amounts of Desulfovibrio and Methanobacteriaceae SSU rRNA $(r=0.51 \quad \mathrm{P}<0.01)$ throughout the observation period.

Intestinal ciliates and their endosymbionts from the cockroach hindgut: evolutionary aspects. AHAM Van Hoek, TA Van Alen, VSI Sprakel, JHP Hackstein, GD Vogels (Deptartment of Microbiology and Evolutionary Biology, University of Nijmegen, NL-6525 ED Nijmegen, The Netherlands)

Anaerobic ciliates occur in the hindgut of many cockroach species, but only in those cockroaches that also are host to intestinal methanogens. Such ciliates contain, without exception, endosymbiotic methanogenic bacteria [1]. Although all of these anaerobic ciliates seem to be related to Nyctotherus sp. behavioural studies (e.g. galvanotaxis) and the morphology of the methanogenic endosymbionts suggest the presence of different protists in the various cockroach species. The rDNA genes of individual ciliates and their methanogenic endosymbionts were analysed in order to study the symbioses. DNA sequencing and restriction analysis of PCR-amplified rDNA genes showed that the ciliates isolated from the various cockroach hosts did differ significantly. The endosymbiotic methanogenic bacteria of these ciliates, also, proved to be different. Thus, in contrast to the situation in aphids with their eubacterial endosymbionts [2], the phylogeny of the anaerobic ciliates and their cockroach hosts [3] does not match. Since the methanogenic endosymbionts also differ substantially, it seems reasonable to conclude that the symbioses between methanogenic bacteria, ciliates, and cockroaches evolved more than once.

1. Hackstein JHP, Stumm CK (1994) Proc Natl Acad Sci USA 91, 5441-5445

2. Moran NA (1996) Proc Natl Acad Sci USA 93, 2873-2878

3 Kambhampati S (1995) Proc Natl Acad Sci USA 92, 2017-2020

\section{MICROBIAL GENETICS}

Transformation of Butyrivibrio $f i$ brisolvens strains with $\mathrm{pBH}_{\mathrm{f}}$ plasmid. J Kopecny. ${ }^{1}$, K Fliegerová ${ }^{1}, \mathrm{~K}$ Gregg $^{2}$ ('Institute of Animal Physiology and Genetics, Czech Academy of Sciences, Prague 10, Uhoinives, 104 00, Czech Republic; ${ }^{2}$ Institute of Biotechnology, University of New England, Armidale, NSW 2351, Australia) 